\title{
FAKTOR PENYEBAB PERBEDAAN PRESTASI BELAJAR MATA PELAJARAN PENDIDIKAN AGAMA ISLAM (PAI) ANTARA PESERTA DIDIK YANG BERASAL DARI KELUARGA GURU DAN BURUH TANI
}

\author{
Dina Fitria Agustina ${ }^{1}$, Olan Maulana ${ }^{2}$ \\ dinafitriaagustina2@gmail.com,olan.maulana28@gmail.com
}

\begin{abstract}
Abstarak
Pendidikan adalah sebagai usaha sadar dan terencana untuk mewujudkan suasana belajar dan proses pembelajaran untuk peserta didik secara aktif mengembangkan potensi dirinya untuk memiliki kekuatan spiritual keagamaan, pengendalian diri, kepribadian, kecerdasan, akhlak mulia, serta keterampilan yang diperlukan dirinya dan masyarakat. Orang tua memiliki peran yang penting dalam kemajuan dan prestasi belajar anak atau peserta didik, begitu juga status sosial orang tua akan turut mempengaruhi prestasi belajar peserta didik termasuk terhadap prestasi belajar.

Oleh sebab itu penulis mengajukan rumusan masalah "Faktor apa yang menyebabkan prestasi belajar peserta didik yang berasal dari keluarga guru lebih rendah dari pada prestasi belajar peserta didik yang berasal dari keluarga buruh tani di SMAN 1 Gunung Sugih Kabupaten Lampung Tengah"?. Penelitian ini bertujuan untuk mengetahui faktor apa saja yang menyebabkan perbedaan prestasi belajar PAI antara peserta didik yang berasal dari keluarga guru dan buruh tani. Penelitian ini adalah penelitian lapangan yang bersifat kualitatif deskriptif, di dalam menghimpun dan mengumpulkan data dari lokasi penelitian, digunakan beberapa alat pengumpul data di antaranya metode interview sebagai metode pokok, kemudian metode observasi, dan dokumentasi sebagai metode pendukung, sedangkan dalam menganalisa data penulis menggunakan cara induktif.

Hasil penelitian ini disimpulkan bahwa terdapat perbedaan yang signifikan terkait prestasi belajar Peserta didik yang berasal dari keluarga guru dan buruh tani di SMAN 1 Gunung Sugih. Prestasi belajar Peserta didik yang berasal dari keluarga buruh tani lebih baik bila dibandingkan dengan prestasi belajar Peserta didik yang berasal dari keluarga guru. Faktor yang sangat berpengaruh terhadap prestasi belajar Peserta didik yaitu : Kurangnya kesadaran diri terhadap betapa pentingnya belajar di sekolah maupun dirumah, keterbatasan dari segi materi dan dukungan dari orang tua bagi Peserta didik yang berasal dari buruh tani tidak menjadi kendala yang begitu berat dalam meraih prestasi belajar yang baik.
\end{abstract}

Kata kunci: Faktor penyebab perbedaan prestasi belajar mata pelajaran Pendidikan Agama Islam dan Peserta didik yang berasal dari keluarga guru dan buruh tani. 
Pendidikan merupakan suatu keharusan bagi manusia karena pada hakikatnya manusia lahir dalam keadaan tidak berdaya, tidak langsung dapat berdiri sendiri dan tidak dapat memelihara dirinya sendiri. Manusia pada saat lahir sepenuhnya memerlukan bantuan orang tuanya. Karena itu pendidikan merupakan bimbingan orang dewasa mutlak diperlukan manusia.

"Pendidikan sebagai usaha manusia untuk menumbuhkan dan mengembangkan potensi-potensi pembawaan baik jasmani maupun rohani sesuai dengan nilai-nilai yang ada di dalam masyarakat dan kebudayaan. Usaha-usaha yang dilakukan untuk menanamkan nilai-nilai dan norma-norma tersebut serta mewariskannya kepada generasi berikutnya untuk dikembangkan dalam hidup dan kehidupan yang terjadi dalam suatu proses pendidikan."

Seperti yang dituliskan dalam Undang-Undang Nomor 20 tahun 2003 tentang Sistem Pendidikan Nasional, Pasal 3, tujuan pendidikan nasional adalah "Mengembangkan potensi peserta didik agar menjadi manusia yang beriman dan bertakwa kepada Tuhan Yang Maha Esa, berakhlak mulia, sehat, berilmu, cakap, kreatif, mandiri, dan menjadi warga negara yang demokratis serta bertanggung jawab". ${ }^{2}$

"Lingkungan keluarga merupakan lembaga pendidikan yang pertama dan utama bagi anak. Disebut sebagai lingkungan pendidikan pertama, karena di sinilah anak mengenal dunia pertama kalinya, lingkungan di luar dirinya. Kemudian disebut sebagai lingkungan pendidikan yang utama bagi anak, karena keberhasilan pendidikananak dalam keluarga ketika anak berada dalam usia dini yang dikenal juga sebagai usia emas (golden age), akan sangat berpengaruh pada keberhasilan pendidikan pada periode perkembangan anak berikutnya. Karena itulah keluarga dipandang sebagai lingkungan pendidikan yang pertama dan utama.",3

Dari pendapat di atas, bahwa jelas peran orang tua dalam keluarga bisa menjadi tolak ukur dalam perkembangan pendidikan dan pribadi anaknya. Peran keluarga merupakan peran yang sangat sentral dan penting, karena keluarga merupakan tempat pertama bagi anak mendapatkan pendidikan dan tempat dimana anak mendapatkan perhatian serta pengawasan dari orang tuanya tentang berbagai hal yang telah ia dapatkan di sekolah. Sehingga orang tua dapat mempengaruhi sikap dan motivasi anaknya dalam mencapai prestasi belajarnya

Dalam berbagai firman Allah SWT memberitahukan kepada kita, bahwa dalam evaluasi terhadap peserta didik adalah merupakan suatu tugas penting dalam rangkaian proses pendidikan guna menuju hasil atau prestasi belajar yang telah dilaksanakan dalam pendidikan. Hal ini dapat dipahami dari ayat-ayat berikut ini:

\footnotetext{
${ }^{1}$ Fuad Ihsan, Dasar-dasar kependidikan: komponen MKDK (Jakarta: Rineka Cipta, 2008), h.2.

${ }^{2}$ Redaksi Sinar Grafika, UU Sistem Pendidikan Nasional (UU RI No. 20 Tahun 203) (Jakarta: Sinar Grafika, 2014), h.50.

${ }^{3}$ Helmawati, Pendidikan KeluargaTeoritis dan Praktis (Bandung: PT Remaja Rosdakarya, 2014), h.44.
} 


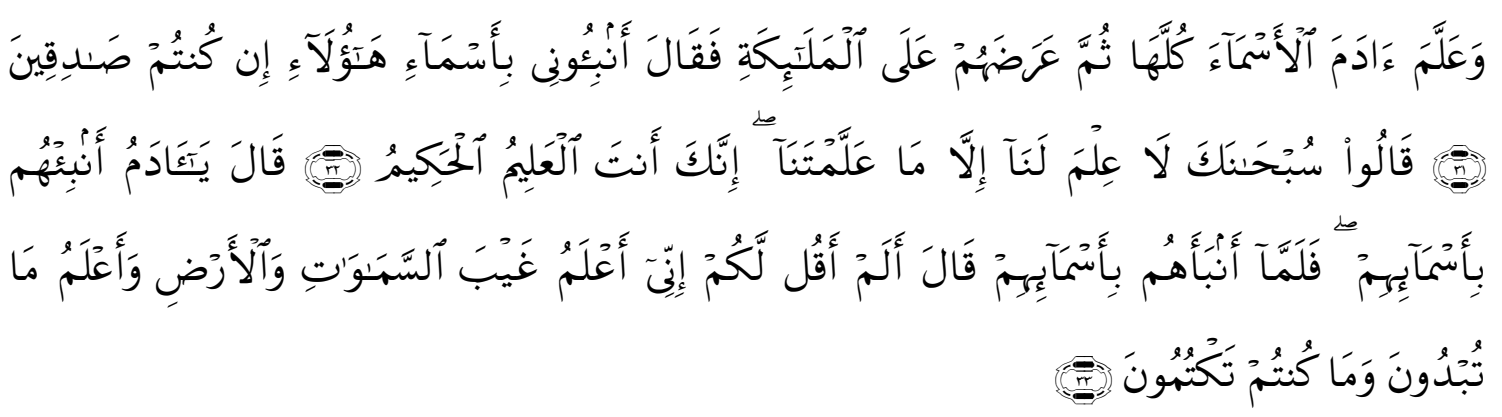

Artinya: Dan dia mengajarkan kepada Adam nama-nama (benda-benda) seluruhnya, Kemudian mengemukakannya kepada para malaikat lalu berfirman: "Sebutkanlah kepada-Ku nama benda-benda itu jika kamu mamang benar orang-orang yang benar!" Mereka menjawab: "Maha Suci Engkau, tidak ada yang kami ketahui selain dari apa yang Telah Engkau ajarkan kepada Kami; Sesungguhnya Engkaulah yang Maha mengetahui lagi Maha Bijaksana." Allah berfirman: "Hai Adam, beritahukanlah kepada mereka nama-nama benda ini." Maka setelah diberitahukannya kepada mereka nama-nama benda itu, Allah berfirman: "Bukankah sudah Ku katakan kepadamu, bahwa Sesungguhnya Aku mengetahui rahasia langit dan bumi dan mengetahui apa yang kamu lahirkan dan apa yang kamu sembunyikan?" (Al Baqarah:31-33)

Hal ini tidak menutup kemungkinan bahwa tugas dan peran orang tua juga mempengaruhi prestasi belajar peserta didik. Pendapat Samsul Munir mengenai orangtua (bapak\&Ibu) sebagai berikut:

Ibu adalah orang yang mengandung dan sejak mengandung telah terjadi kontak komunikasi antara janin yang dikandungnya. Kedudukan ibu dalam pendidikan anaknya sangat besar artinya seorang ibu telah mengandung jabang bayi kurang lebih 9 bulan. Kemudian menyusui kurang lebih 2 tahun, merawatnya dengan penuh kasih sayang dan demikian seterusnya sampai mendidik anak.Bapak merupakan seorang kepala rumah tangga yang sangat menentukan terhadap keberhasilan anak. Ayah berperan dalam menyediakan kebutuhan keluarga dan anak-anaknya. ${ }^{4}$

"Selain itu peserta didik yang berasal dari keluarga guru biasanya lebih terlihat acuh dan biasa saja dalam menerima pelajaran ataupun dalam proses belajar dikelas, dikarenakan mereka beranggapan bahwasannya dengan status sosial orang tuanya yang menjadi guru, mereka akan mendapat nilai yang sesuai dengan keinginan atau kehendak mereka walaupun dalam kenyataannya minat belajar mereka sangat kurang. Atau ada faktor lain yang menyebabkan mereka tidak aktif untuk belajar dikelas seperti misalnya motivasi dan perhatian orang tua atau pengaruh lingkungan diluar. Lain halnya dengan peserta didik yang status orang tuanya sebagai buruh tani mereka cenderung lebih aktif dikelas, dikarenakan mereka memiliki motivasi yang besar untuk meraih prestasi yang tinggi sehingga mereka dapat merubah kehidupan dan pandangan orang tentang pekerjaan orang tuanya sebagai buruh tani.",

\footnotetext{
${ }^{4}$ Samsul Munir Amin, Menyiapkan Masa Depan Anak secara Islami, (Jakarta: Amzah, 2007), hal. 19.

${ }^{5}$ Sahidin, Guru Pendidikan Agama Islam SMAN 1 Gunung Sugih, Wawancara, tanggal 5 Januari 2017.
} 
Menurut Roberson Sinaga,perbedaan status sosial orang tua, seperti orang tua bekerja sebagai guru dan buruh tanimembawa pengaruh terhadap prestasi belajar peserta didik. Biasanya Orang tua yang bekerja sebagai guru memiliki perhatian yang lebih besar terhadap pendidikan dan prestasi belajar anaknya dari pada orang tua yang bekerja sebagai buruh tani. Namun di zaman sekarang justru lebih banyak anak yang berasal dari keluarga buruh tani lebih meningkat prestasinya dibanding dengan anak yang berasal dari keluarga guru, dikarenakan mereka lebih termotivasi untuk merubah kehidupannya menjadi lebih baik dari orang tuanya, sehingga mereka akan terus belajar dengan giat agar dapat meraih prestasi yang membanggakan dan tidak kalah saing dengan anak yang berasal dari keluarga guru. Namun sekarang banyak dari anak yang berasal dari keluarga guru kurang sekali motivasi dan minat untuk belajar hal ini dapat disebabkan oleh kurangnya perhatian orang tua dirumah dan pengawasan terhadap anaknya. $^{6}$

Karena orang tua yang bekerja sebagai buruh tani tidak mengerti bagaimana cara memotivasi anak agar prestasinya lebih meningkat, yang mereka bisa hanyalah menyekolahkan anaknya agar anak mereka lebih pandai serta tidak bisa memberikan sarana dan prasarana yang dibutuhkan anak, karena keterbatasan ekonomi mereka dan ketidaktahuan orang tua, yang orang tua tahu mereka menyekolahkan anak mereka agar menjadi pintar dan dapat merubah nasibnya menjadi lebih baik tidak seperti orang tuanya. Tetapi kenyataan yang ada di zaman sekarang malah berbanding terbalik dengan pernyataan yang ada. Anak yang berasal dari keluarga buruh tani justru lebih baik prestasinya dibandingkan dengan anak yang berasal dari keluarga guru".?

Berdasarkan pemaparan dan fenomena di atas, penulis tertarik untuk mengkaji dan meneliti tentang faktor-faktor yang menyebabkan perbedaan prestasi belajar mata pelajaran Pendidikan Agama Islam antara peserta didik dari keluarga guru dan buruh tani di SMAN 1 Gunung Sugih Kabupaten Lampung Tengah.

\section{HASIL KAJIAN DAN PEMBAHASAN}

Dalam proses analisa data ini terutama untuk memperoleh kesimpulan akhir yang akurat maka terlebih dahulu diadakan reduksi data yakni untuk memilih data yang relevan dan bermakna dengan masalah penelitian. Kemudian data telah dipilih dan di sajikan dalam bentuk gerasi (dispay) yakni di uraikan secara rinci selanjutnya memberikan penafsiran terhadap hasil penelitian sehingga mudah dalam menganalisa dan membuat kesimpulan atau verifikasi. Verifikasi akan di lakukan dengan melihat kembali pada reduksi data maupun display data, sehingga kesimpulan yang diambil tidak menyimpang dari data yang dianalisa.

Data yang diperoleh akan dianalisa dengan kata-kata atau kualitatif. Setelah data dianalisa kemudian diambil kesimpulan dengan cara berfikir induktif yaitu berfikir dengan berangkat dari fakta-fakta yang khusus kemudian di tarik kesimpulan yang bersifat umum. Dengan demikian maka dapat dihindari kesalahan dalam mengambil kesimpulan.

\footnotetext{
${ }^{6}$ Roberson Sinaga, SMAN 1 Gunung Sugih, Wawancara, tanggal 5 Januari 2017.

${ }^{7}$ Roberson Sinaga, Kepsek SMAN 1 Gunung Sugih, Wawancara, tanggal 5 Januari 2017.
} 
Adapun analisa dari data yang di peroleh penulis tentang perbedaan prestasi belajar peserta didik yang berlatar belakang keluarga buruh tani dan guru di SMAN 1 Gunung Sugih Kabupaten Lampung Tengah melalui observasi yang dilakukan dan terlampir pada lampiran observasi menunjukan adanya perbedaan yang mana peserta didik yang berasal dari keluarga buruh tani lebih aktif mengikuti proses belajar dengan baik sehinga materi yang di sampaikan oleh dapat di pahami dengan baik. Sedangkan peserta didik yang berasal dari keluarga guru kurang aktif dalam mengikuti proses belajar mengajar, itu berdampak terhadap hasil belajar, sehinnga berpengaruh terhadap prestasi belajar peserta didit itu sendiri.

Untuk menambah ke akuratan hasil penelitian ini maka peneliti melakukan analasisi hasil interview dengan Kepala Sekolah, Guru, peserta didik, dan Orang tua Peserta didik kelas XI IPA 1 dan X1 IPA 3.

Untuk mencari data yang diperlukan terlebih dahulu penulis melakukan interview dengan kepala sekolah pada tanggal 20 Juli 2017 sebagai berikut:

1. Bagaimana kinerja guru-guru PAI yang ada di SMAN 1 Gunung Sugih dalam meningkatkan prestasi belajar Peserta didik pada mata pelajaran Pendidikan Agama Islam?

Jawab: Kinerja guru PAI di sekolah ini baik karena sekolah selalu memantau kinerja guru dan melakukan evaluasi.

Interpretasi: Dari jawaban kepala sekolah ini dapat di simpulkan bahwasannya kinerja guru di SMA N 1 Gunung Sugih Kabupaten Lampung Tengah ini selalu terpantau dan selalu dilakukan evaluasi guna memperbaiki kinerja guru mata pelajaran terkait.

2. Apakah ada kreteria khusus bagi guru PAI di SMAN 1 Gunung Sugih guna meningkatkan hasil prestasi belajar peserta didik dalam mata pelajaran PAI?

Jawab: Tentunya kami melakukan seleksi terlebih dahulu bagi guru guru yang mengajar termasuk guru PAI juga tidak luput dari seleksi yang kami adakan ketika guru melamar di sekolah kami, khusus bagi guru PNS, karena mereka ditentukan dari pemerintah jadi mereka hanya terkena Upgeding (Peningkatan kemamapuan dalam bidangya)

Interpretasi: Dalam hal ini sekolah sangat selektip dalam melakukan kebijakan guna terwujudnya tujuan pendidikan.

3. Upaya apa yang dilakukan sekolah dalam meningkatkan prestasi belajar Peserta didik di SMAN 1 Gunung Sugih Kabupaten Lampung Tengah khususnya pada Pendidikan Agama Islam?

Jawab: Tentunya ada, sekolah selalu memantau kegiatan yang dilakukan di sekolah selain itu sekolah juga selalu mengadakan pelatihan guru-guru guna meningkatkan ke profesionalan guru, di sisi lain sekolah memenuhi kebutuhan sarana dan prasarana guna menunjang tercapainya tujuan pendidikan

Interpretasi: Dalam hal ini sekolah selalu memantau dan memberikan dukungan dukunganya baik berbentuk pelatihan guru atau sarana prasarana kebutuhan belajar, sehingga menghasilkan lulusan yang berkualitas.

Untuk menambah informasi terkait dengan fator penyebab perbedaan hasil belajar Peserta didik, penulis juga melakukan interview dengan Guru Pendidikan Agama Islam di SMAN 1 Gunung Sugih Kabupaten Lampung Tengah pada tangal 20 Juli 2017:

1. Sejak kapan bapak/ibu menjalankan tugas sebagai guru Pendidikan Agama Islam? 
Jawab: Sejak tahun 2009 saya mengajar di sekolah ini dengan latar belakang S1 Pendidikan Agama Islam.

Interpretasi: Dengan waktu yang cukup lama dan latar belakang yang memang dari jurusan Pendidikan Agama Islam guru PAI di sekolah ini bisa dikatakan profesional.

2. Bagaimana minat dan perhatian sisiwa dalam mengikuti proses belajar mata pelajaran PAI di dalam kelas?

Jawab: Cukup baik dan hampir keseluruhan Peserta didik sangat asik dan berminat ikut aktif dalm mengikuti proses pembelajaran Pendidikan Agama Islam. Meskipun ada beberapa Peserta didik yang terllihat tidak aktif saat pembelajaran berlangsung.

Interpretasi: Dari pemaparan jawaban di atas menunjukan perhatian dan keinginan Peserta didik dalam mengikuti proses belajar mengajar mata pelajaran Pendidikan Agama Islam.

3. Metode apa saja yang bapak/ibu terapkan dalam mengajarkan mata pelajaran Pendidikan Agama Islam di kelas?

Jawab: Banyak sekali metode yang saya gunakan dikelas saya memilih metode itu menyesuaikan materi apa yang akan dibahas pada pertemuan setiap proses belajar mengajar akan dilaksanakan dan sudah saya cantumkan dalam RPP.

Interpretasi: Dilihat dari jawaban guru diatas menunjukan keprofesionalan seorang guru yang mana sebelum proses belajar mengajar belangsung guru sudah mempersiapkan terlebih dahulu kebutuhan proses belajar mengajar.

4. Bagaimana kondisi media pembelajaran Pendidikan Agama Islam?

Jawab: Media pembelajaran di sekolah ini cukup baik karena selalu memperbaharui dan memenuhi kebutuhan kebutuhan belajar selain itu pemerintah juga mendukung.

Interpretasi: Media pembelajaran yang tesedia selalu mengalami pembaharuan dengan cara menganti atau memperkaya misalkan buku buku lama dengan bukubuku baru dengan menyesuaikan kedalam kuriku yang berlaku serta bantuan adari pemerintah sangat mempengruhi dan dibutuhkan pihak sekolah.

5. Bagaimana hasil prestasi belajar mata pelajaran PAI antara Peserta didik yang berasal dari keluaraga Guru dan Buruh Tani?

Jawab: Ada perbedaan yang cukup signifikan yanag membedakan prestasi belajar mereka

Interpretasi: Jadi jelas perbedaan yang cukup signifikan ini akan menjadi titik tolak dilakukanya penelitian ini guna memecahkan permasalahan tersebut.

6. Apakah peserta didik menguasai bahan ajar setelah proses pembelajaran?

Jawab: Setelah dilakukan evaluasi tidak semua peserta didik menguasai bahan ajar yang diajarkan ada beberapa \% yang tidak menguasai bahan ajar secara makasimal maka dari itu saya selalu melakukan review sebelum jam belajar berakhir

Interprestasi: Dari jawaban tersebut dapat dilihat upaya guru dalam memeberikan pembelajaran secara maksimal.

7. Bagaimana tindakan bapak/ibu guru dalam meningkatkan prestasi belajar Peserta didik?

Jawab: Saya selalu melakukan evalusi sebelum dan sesudah proses belajar mengajar belangsung serta saya memberikan tugas tambahan dirumah. 
Interpretasi: Dari jawaban tersebut dapat disimpulkan bahwa ada upaya guru Pendidikan Agama Islam dalam mengupayakan meningkatkan prestasi belajar sisiwa di sekolah SMAN 1 Gunung Sugih Lampung Tengah.

Selanjutnya guna memperkuat data yang diperlukan oleh penulis, melakukan interview dengan reponden yaitu Peserta didik kelas XI IPA 1 dan XI IPA 3 :

1. Apakah anda dirumah belajar mata pelajaran PAI?

Jawab: Terlampir di lampiran 3 dan 4

Interpretasi: 100\% Responden (11 dari kelurga Guru, 21 dari keluarga Buruh Tani dan 8 peserta didik dari kelurga Wiraswasta) menjawab "YA" melakukan proses belajar Pendidikan Agama Islam dirumah.

2. Apakah anda selalu diawasi orang tua ketika belajar di rumah?

Jawab: Terlampir di Lampiran

Interpretasi: Dari 40 Peserta didik hanya 35\% Peserta didik yang belajar di awasi oleh wali yang mana dari $35 \%$ ini yang menjadi dominan adalah Peserta didik yang berasal dari keluarga Guru, sedangkan $65 \%$ tidak pernah di awasi orang tua ketika belajar di rumah.

3. Apakah anda memiliki buku pelajaran mata pelajaran PAI untuk belajar?

Jawab: Terlampir di lampiran 3 dan 4

Interpretasi: $100 \%$ Peserta didik memiliki panduan belajar PAI, ini menunjukan tidak ada alasan untuk Peserta didik tidak belajar dirumah terkait mata pelajaran PAI.

4. Apakah orang tua anda selalu membimbing ketika belajar dirumah?

Jawab: Terlampir di lampiran 3 dan 4

Interpretasi: Dari 40 responden 30\% Peserta didik yang menjawab YA, yang mana dari $30 \%$ tersebut masih di dominasi oleh Peserta didik yang berasal dari keluarga guru dan $70 \%$ Peserta didik menjawab tidak dibimbing belajar PAI dirumah.

5. Apakah orang tua anda selalu menayakan hasil belajar atau nilai PAI anda?

Jawab: Terlampir di lampiran 3 dan 4

Interpretasi: $72,5 \%$ Peserta didik tidak pernah ditanya oleh orangtua terkait dengan hasil nilai yang diperolehnya hanya sebagian kecil saja orang tua yang menanyakan hasil belajar anaknya yaitu sekitar 27,5\% yang mana dari $27,5 \%$ tersebut masih di dominasi oleh Peserta didik yang berasal dari keluarga Guru.

6. Bagaimana sikap orang tua anda ketika melihat anda tidak belajar?

Jawab: Hampir 100\% Peserta didik yang berasal dari keluarga Guru menjawab menerima teguran dan di berinasihat agar belajar, namun 50\% Peserta didik yang berasal dari keluarga buruh tani menjawab biasa saja tidak ada respon dari orang tuanya dan $50 \%$ nya lagi mengalami teguran dan nasihat dari orangtuanya supaya belajar.

Interpretasi: Dari jawaban diatas dapat disimpulkan bahwa orang tua Peserta didik yang bekerja sebagai Guru sangat memperhatikan anaknya terkait belajar anaknya ketika dirumah. Lain halnya dengan oranng tua yang berasal dari keluarga buruh tani yang kurang merespon aktivitas anaknya ketika belajar di rumah.

7. Apakah materi pelajaran yang disampaikan oleh guru, kalian bisa memahaminya dengan baik? 
Jawab: Peserta didik di kelas XI IPA 1 dan XI IPA 3 menjawab dapat memahami pelajaran yang di berikan oleh guru Pendidikan Agama Islam di sekolah

Interpretasi: Dari jawaban di atas dapat di simpulkan bahwa tidak ada masalah dalam hal pembelajaran di sekolah karena sisiwa dapat memahami pelajaran PAI yang diberikan oleh guru.

8. Usaha apa yang anda lakukan untuk meningkatkan prestasi belajar dalam mata pelajaran Pendidikan Agama Islam ?

Jawab: Belajar dirumah dan belajar tambahan di lembaga bimbingan belajar

Interpretasi: Dari jawaban diatas dapat di simpulkan bahwasannya Peserta didik paham akan kebutuhannya ketika ia ingin meningkatkan prestasi belajarnya di sekolah.

Penulis juga melakukan interview dengan orang tua peserta didik yang berasal dari keluarga Guru dan Buruh Tani.

1. Apakah bapak/ibu mengawasi belajar anak ketika di rumah

Jawab: 20 Wali murid menjawab YA dan 20 Wali murid menjawab kurang (tidak) mengawasi belajar anak ketika dirumah

Interprestasi: Berdasarkan hasil Interview di atas bisa di tarik kesimpulan bahwa 50\% yang dominan dari kategori Guru memperhatikan/ mengawasi belajar anak ketika di rumah dan $50 \%$ wali murid yang dominan berasal dari buruh tani yang tidak/kurang memperhatikan belajar anak ketika dirumah dengan alasan mereka terlalu mempercayakan pendidikan anaknya kepada pihak sekolah yakni SMAN 1 Gunung Sugih.

2. Apakah bapak/ibu memberikan bimbingan belajar kepada anak ketika dirumah?

Jawab: Sebagian wali murid yang berasal dari keluarga Buruh Tani tidak pernah memberikan bimbingan belajar namun memberikan fasilitas belajar kepada anaknya dan 100\% Wali dari kategori Guru mereka memberikan bimbingan belajar kepada anaknya ketika dirumah serta memberikan motivasi belajar.

Interpretasi: Dari jawaban diatas dapat ditarik kesimpulan bahwa sebagian besar wali murid hanya memberikan fasilitas belajar tanpa memberikan bimbingan dalam proses belajar.

3. Apakah bapak/ibu menyedikan buku panduan belajar untuk anak dirumah?

Jawab: Semua wali murid menjawab iya menyediakan buku panduan Pendidikan agama Islam.

Interprestasi: Memang semua wali murid ikut serta dalam memberikan pasilitas belajar Peserta didik dirumah karena pada kaliin sekolah juga ikut menjembatani Peserta didik / walimurid dalam hal menyediakan buku panduan.

4. Apakah bapak/ibu mengawasi perkembangan anak di rumah?

Jawab: Pada item ini mayoritas orang tua yg berstatus sebagai buruh tani tidak mengawasi perkembangan anaknya dikarenakan sibuk dengan pekerjaanya sebagai buruh tani namun berbanding terbalik dengan wali yang berstatus guru yang selalu mengawasi perkembangan anaknya.

Interprestasi: Berdasarkan dari jawaban diatas maka dapat di simpulkan bahwasanya wali yang berstatus buruh tani keterbatasan waktu dan pengetahuan akan dunia pendidikan yang membuat wali kurang memperhatikan perkembangan anaknya, sedangkan wali yang berstatus Guru memiliki 
pengetahuan dan waktu yng cukup untuk memperhatikan akan perkembangan anaknya.

5. Bagaimana cara bapak/ibu dalam meningkatkan hasil belajar anak ketika hasilnya kurang baik?

Jawab: Keluarga Buruh menjawab hanya menegur dan meminta anaknya supaya belajar yang rajin disekolah sedangkan keluarga yang berasal dari Guru memberikan perlakuan khusus kepada anaknya dengan memberikan jam belajar tambahan dengan mengirim anaknya untuk belajar di lembaga kursus atau bimbingan belajar.

Intervrestasi: Dari jawaban diatas dapat di simpulkan bahwa wali Peserta didik yang bekerja sebagai buruh tani hanya memberikan arahan saja tanpa memberikan solusi yang nyata di karenakan keterbatasan biaya, lain halnya wali yang bekerja sebagai Guru yang memiliki nilai lebih dalam hal materi dan pengetahun sehingga mereka memberikan solusi dengan memberikan jam tambahan bagi anaknya.

6. Bagaimana sikap bapak/ibu ketika melihat prestasi belajar anaknya baik/kurang baik?

Jawab: Semua wali menjawab hal yang sama mereka ketika prestasi anaknya buruk mereka kecewa dan memberi nasihat agar memperbaiki prestasi belajarnya dan ketika prestasi anaknya baik mereka merasa bangga.

Interpretasi: Dari jawaban diatas bahwasanya semua orang tua memiliki keinginan yang sama yaitu prestasi anaknya baik namun keterbatasanlah yang membuat sebagian wali tidak terlalu ikut andil dalam hal meningkatkan prestasi anaknya.

Berdasarkan hasil Interview dengan Kepala sekolah, Guru, Peserta didik dan orang tua Peserta didik di SMAN 1 Gunung Sugih Lampung Tengah di atas maka dapat diinterpretasikan dan dianalisa bahwa faktor penyebab perbedaan prestasi belajar yaitu kesadaran diri untuk mengendalikan diri yang berfungsi sebagai pengendali diri yang berada pada diri seseorang sehingga belajar akan penuh kesadaran tanpa adanya paksaan.

Selain itu Peserta didik dari keluarga Buruh tani pretasi belajarnya lebih baik dari pada Peserta didik yang yang berlatar belakang keluarga Guru hal tersebut dikarenakan berbeda pola belajar, Peserta didik yang berasal dari keluarga Guru terlalu di tuntut dan di paksa belajar guna mencapai prestasi belajar di sekolah sehingga anak mengalami tekanan dan mengikuti apa yang di inginkan orang tua sedangkan kesadaran pada dirinya masih kurang akan tanggung jawabnya. Hal tersebut tidak terjadi dengan Peserta didik yang berasal dari keluarga buruh tani di mana dari keterbatasan hal-hal yang dimiliki oleh Peserta didik yang berasal dari keluarga guru menjadi motivasi yang membentuk kesadaran pada dirinya akan kewajibannya sebagi seorang Peserta didik dan tanggung jawabnya kepada kedua orangtua yang telah membiayai pendidikannya disekolah dan berharap anak-anaknya mampu berprestasi dengan baik.

\section{METODE PENELITIAN}

Adapun jenis penelitian yang penulis lakukan adalah penelitian kualitatif deskriptif yaitu suatu proses penelitian yang dilakukan secara wajar dan natural sesuai dengan kondisi objektif dilapangan tanpa adanya manipulasi, serta jenis data yang dikumpulkan terutama data kualitatif. Proses penelitian yang dimaksud antara lain 
melakukan observasi terhadap orang dalam kehidupannya sehari-hari. Kajian utama penelitian kualitatif adalah fenomena atau kejadian yang berlangsung dalam suatu situasi sosial tertentu. ${ }^{8}$

\section{KESIMPULAN}

Setelah dilakukan serangkaian penelitian dan mengolah serta menganalisis datadata yang di peroleh pada Kelas XI IPA 1 dan XI IPA 3 SMA N 1 Gunung Sugih Kabupaten Lampung Tengah, maka penulis dapat menarik kesimpulan bahwa factor factor yang mempengaruhi pebedaan prestasi belajar peserta didik dari keluarga guru dan buruh tani adalah:

1. Kurangnya kesadaran diri terhadap betapa pentingnya belajar di sekolah maupun dirumah,

2. Perbedaan Kemamapuan,

3. Kurangya minat dalam belajar baik di sekolah dan di rumah

4. Kurangya motivasi

5. Faktor Lingkungan

6. Keterbatasan dari segi materi dan dukungan dari orang tua bagi peserta didik yang berasal dari buruh tani tidak menjadi kendala yang begitu berat dalam meraih prestasi belajar yang baik.

\section{DAFTAR PUSTAKA}

Abdul Majid dan Dian Andayani, Pendidikan agama Islam Berbasisi Kompetensi: Konsep dan Implementasi Kurikulum 2004, Bandung: PT. Remaja Rosda Karya, 2004.

Abdul Mujib, Ilmu Pendidikan Islam, Jakarta : Kencana, 2010.

Abdul Rahman Shaleh, Pendidikan Agama dan Keagamaan, Jakarta:PT. Gemawindu Pancaperkasa, 2000.

Abdul Wahab Khalaf, Ilmu Ushul Fiqh, Jakarta: Gema Insani Press, 2007.

Ahmad Tafsir, Ilmu Pendidikan dalam Perspektif Islam, Bandung: PT. Remaja Rosdakarya, 2007.

Anas Sudjono, Statistik Pendidikan, Jakarta : PT. Raja Grafindo Persada, 2004.

Armai Arief, Reformulasi Pendidikan Islam, Jakarta: CRSD Press Jakarta, 2005.

Departemen Agama RI, Al Quran dan Terjemahan, Bandung : Diponegoro, 2006.

Laporan Penilaian Hasil Belajar, Jakarta : Percetakan Negara, 2004.

\footnotetext{
${ }^{8}$ Zainal Arifin, Penelitian Pendidikan, (Bandung : Remaja Rosdakarya, 2014), h.140.
} 
, Undang-Undang dan Peraturan Pemerintah RI Tentang Pendidikan, Jakarta: Direktorat Jendral Pendidikan Islam Departemen Agama Islam, 2006.

Departemen Pendidikan dan Kebudayaan,Kamus Besar Bahasa Indonesia, Jakarta : Balai Pustaka, 2012.

E. Mulyasa, Menjadi Guru Profesional, Bandung : Remaja Rosdakarya, 2007. Rosdakarya, 2007.

Fuad Ihsan, Dasar-dasar kependidikan: komponen MKDK, Jakarta: Rineka Cipta, 2008.

H. Djaali, Psikologi Pendidikan, Jakarta : PT. Bumi Aksara, 2014.

Hamdu, Ghullam, and Lisa Agustina. "Pengaruh motivasi belajar siswa terhadap prestasi belajar IPA di sekolah dasar." Jurnal penelitian pendidikan 12.12011

Hasbullah, Dasar-Dasar Ilmu Pendidikan: Umum dan Agama Islam, Jakarta: PT. Raja Grafindo Persada, 2006.

Helmawati, Pendidikan Keluarga Teoritis dan Praktis, Bandung: PT Remaja Rosdakarya, 2014.

M.Ngalim Purwanto, Psikologi Pendidikan, Bandung : PT. Remaja Rosdakarya, 2010.

Malik Bin Anas, Al Muwaththa', Kairo: Al Maktaba An Nashiriyah, 2010.

Marzuki, Pendidikan Karakter Islam, Jakarta : Bumi Aksara, 2015.

Moh. Nazir, Metode Penelitian, Bogor: Ghalia Indonesia, 2009.

Mohammad Daud Ali, Pendidikan Agama Islam, Jakarta: Rajawali Pers, 2008.

Muhaimin, et. al, Paradigma Pendidikan Islam, : Upaya Mengefektifkan Pendidikan Agama Islam di Sekolah, Bandung: PT. Remaja Rosdakarya, 2001.

Muhibbin Syah, Psikologi Pendidikan, Jakarta : Rajawali Pers, 2012.

Mikdar, Syaeful, and I. Ali Nurdin. "Pendidikan Agama Islam." 2014

Nana Sudjana, Model-model Mengajar CBSA, Bandung : Sinar Baru, 2010.

Novan Ardy Wiyani, Ilmu Pendidikan Islam, Jogjakarta: Ar-Ruzz Media, 2012.

Ningsih, Nuroktya. "Hambatan Guru Pendidikan Kewarganegaraan dalam Pelaksanaan Evaluasi Pembelajaran di SMAN 1 Sanden." Jurnal Citizenship 1.2. 2013

Umar Tirtaraharja dan S,L La sulo, Pengentar Pendidikan, Rineka Cipta, Jakarta, 2005

Ramayulis,dkk, Pendidikan Islam Dalam Rumah Tangga, Jakarta: Kalam Mulia,cet ke42000. 
Redaksi Sinar Grafika, UU Sistem Pendidikan Nasional (UU RI No. 20 Tahun 203) Jakarta: Sinar Grafika, 2014.

Roberson Sinaga, Kepsek SMAN 1 Gunung Sugih, Wawancara, tanggal 5 Januari 2017.

S. Nasution, Berbagai Pendekatan dalam Proses Belajar Mengajar, Jakarta : Bina Aksara, 2007.

------------, Sosiologi Pendidikan, Jakarta : Bumi Aksara, 2011.

Sahidin, Guru Pendidikan Agama Islam SMAN 1 Gunung Sugih, Wawancara, tanggal 5 Januari 2017.

Samsul Munir Amin, Menyiapkan Masa Depan Anak secara Islami, Jakarta: Amzah, 2007.

Soelaiman Yoesoef, Konsep Dasar Pendidikan Luar Sekolah, Cet.Ke III, Jakarta : Bumi Aksara, 2004.

Sugiyono, Metode Penelitian Kuantitatif, Kualitataif, dan R\&D, Bandung : Alfabeta, 2010 .

Suharsimi Arikunto, Manajemen Pengajaran, Jakarta : Rineka Cipta, 2004.

Cipta, 2010.

Sumadi Suryabrata, Psikologi Pendidikan, Jakarta : Rajawali Pers, 2010.

Syaiful Bahri Djamarah, Guru dan Anak Didik dalam Interaksi Edukatif, Jakarta : Rineka Cipta, 2000.

, Strategi Belajar Mengajar, Jakarta : Rineka Cipta, 2010.

Undang-undang Sisdiknas, Jakarta : Sinar Grafika, 2014.

Uyoh Sadulloh, Pedagogik (Ilmu Mendidik), Bandung: Alfabeta, 2014.

Zainal Arifin, Penelitian Pendidikan, Bandung : Remaja Rosdakarya, 2014.

Zakiah Daradjat, Ilmu Pendidikan Islam, Jakarta : Bumi Aksara, 2014.

Zuhairini, dkk., Metodik Khusus Pendidikan Agama, Surabaya: Usaha Nasional, 2008. 